УДК 821.161.2'06(045)

DOI https://doi.org/10.24919/2308-4863/45-2-11

Ольга МАСЛО, orcid.org /0000-0002-1586-2805 кандидат філологічних наук, доиент,

доиент кафедри украӥнської лінгвістики, літератури та методики навчання Комунального закладу «Харківська гуманітарно-педагогічна академія» Харківської обласної ради (Харків, Україна) olga_maslo@ukr.net

Ірина ВОЛКОВА, orcid.org /0000-0003-4725-8837 кандидат філологічних наук, доцент, доиент кафедри української лінгвістики, літератури та методики навчання Комунального закладу «Харківська гуманітарно-педагогічна академія» Харківської обласної ради (Харків, Україна) irinavolkova2@ukr.net

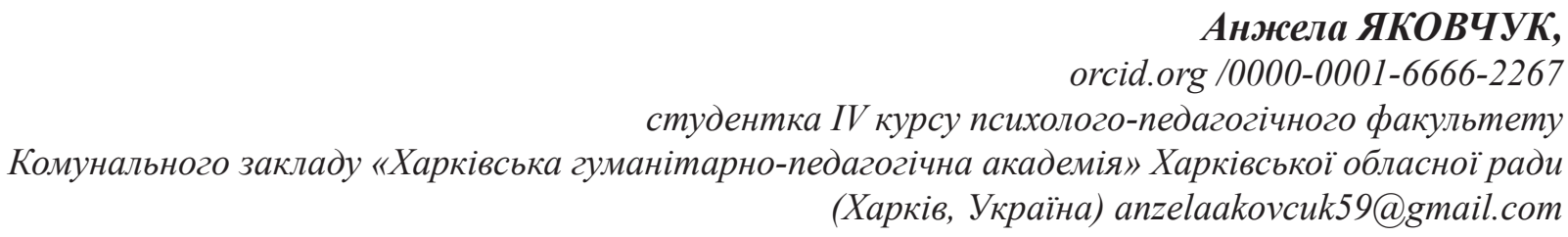
КОМПОЗИЦІЙНІ ПРИЙОМИ ВІДОБРАЖЕННЯ ЧАСОВОГО ПРОСТОРУ

У статті досліджено художній простір $і$ час, які являють собою конкретні, тісно переплетені між собою складники твору; проведено типологічний аналіз специифіки моделювання часопросторових координат, вивчено суть поняття «хронотоп», його взаємозв'язок із жанровою природою твору й прийоми відображення часового простору. Розгянуто можливості теорії хронотопу. Стверджується, що хронотоп $\epsilon$ найважливішим елементом художнього світу твору; моделює взаємозв 'язки картини світу, а тому є одним із найбільш перспективних понять сучасної гуманітарної науки. Залишаючись дискусійними поняттями в літературознавстві, художній час і художній простір корелюється природою самого мистечтва. Художні образи, пов'язані з часопростором, тісно переплетені з філософськими міркуваннями самого наратора. Доведено, щзо хронотоп - це передовсім авторсько-індивідуальний світ, у якому відбиваються події, зображувані в літературному творі, а художній час і простір є важливими засобами вираження інтенції автора. Значущими й показовими для виявлення авторської конщепції світу є часові й просторові характеристики у творі Люко Дашвар «Покров». Ведучи «гру» з часом і простором, автор задіяв можливості для иікавих композииійних багатоходівок, завдяки чому досягнуто справді досконалої архітектоніки. У творі виявлене обрамлення, ретроспекиія, розрив подій у часі, які реалізуються в численних спогадах героїв, листах, снах, «оживленні» подій, засвідчених в архівах тощя. У статті також досліджено використані прийоми зображення соціально-історичного часу, наголошено на характерній подвійній розв'язиі, яка посилює емоційний ефект. Завдяки застосуванню прийому концентричних переходів буття в марення сюжет розгортається в насичені подієвістю структури. Автор часто поєднує теперішній, минулий $і$ майбутній часи в одній змістовій площиині. Для твору Люко Дашвар властиве чергуванням динаміки й статики. Минуле, теперішнє $i$ майбутнє часто співіснують в одному абзаці, іноді автор вдається до кадровості. У творі здебільшого емпірична, видима реальність, щзо є відображенням інформаційного світу структур, у позаемпіричній панує вічність. Зіставляючи різні часопросторові виміри, автор намагався виявити як характеристичні властивості «тут» $i$ «тепер», так $i$ загальні, універсальні закони буття, осмислити світ в його єдності, показати абсурдність ворожнечі. Автор досліджуваного роману майстерно використав просторово-часову композииію як особливий, усвідомлений художній прийом.

Ключові слова: художній простір, часопростір, хронотоп, авторська концепція світу, змістова площина. 
Olga MASLO,
MAOP-1586-2805
orcid.org /0000-0002-15siate Professor at the Department of Ukrainian Linguistics, Literature and Methodology of Education
Candidate of Philology, Associate Professor,
(Kharkov, Ukraine) olga_maslo@ukr.net

Iryna VOLKOVA, orcid.org/0000-0003-4725-8837

Candidate of Philology, Associate Professor, Associate Professor at the Department of Ukrainian Linguistics, Literature and Methodology of Education Kharkiv Humanitarian Pedagogical Academy

(Kharkov, Ukraine) irinavolkova2@ukr.net

\author{
Anzhela YAKOVCHUK, \\ orcid.org /0000-0001-6666-2267 \\ 4th year Student of the Psychological and Pedagogical Faculty \\ Kharkiv Humanitarian Pedagogical Academy \\ (Kharkov, Ukraine) anzelaakovcuk59@gmail.com
}

\title{
COMPOSITIONAL METHODS OF TIME SPACE DISPLAY
}

In the article the artistic space and time, which are specific, closely intertwined components of the work, have been investigated; a typological analysis of the specifics of modeling space-time coordinates has been conducted, the essence of the concept of "chronotope", its relationship with the genre nature of the work and methods of displaying time space has been studied. The possibilities of the chronotope theory are explained. It is argued that the chronotope is the most important element of the artistic world of the work; it models the relationship of the picture of the world, and therefore is one of the most promising concepts of modern humanities. Remaining debatable concepts in literary criticism, artistic time and artistic space are correlated with the nature of art itself. Time-space artistic images are closely intertwined with the philosophical reflections of the narrator himself. It is proved that the chronotope is first of all the author's-individual world, in which the events described in the literary work are reflected, and artistic time and space are important means of expressing the author's intention. The temporal and spatial characteristics in Luko Dashvar's work "The Cover" are significant and indicative for revealing the author's concept of the world. Leading the "game" with time and space, the author used the opportunities for interesting compositional multi-walks, due to which a truly perfect architectonics was achieved. The work reveals framing, retrospection, rupture of events in time, which are realized in numerous memories of heroes, letters, dreams, "revival" of events witnessed in the archives and more. The article also explores the techniques used to depict socio-historical time, emphasizing the characteristic double solution, which enhances the emotional effect. Due to the application of the method of concentric transitions of being into delusions, the plot unfolds into eventful structures. The author often combines present, past and future tenses in one semantic plane. Luko Dashvar's work is characterized by alternating dynamics and statics. The past, present and future often coexist in one paragraph, sometimes the author resorts to staffing. In the work there is mostly empirical, visible reality, which is a reflection of the information world of structures, in the non-empirical reality the eternity prevails. Comparing different space-time dimensions, the author tried to reveal both the characteristic properties of "here" and "now" and the general, universal laws of existence, to comprehend the world in its unity, to show the absurdity of enmity. The author of the researched novel skillfully used the spatio-temporal composition as a special, conscious artistic technique.

Key words: artistic space, time-space, chronotope, author's concept of the world, semantic plane.

Постановка проблеми. Із другої половини ХX ст. в колі наукових зацікавлень літературознавців постає аналізування художнього твору у вимірах часу та простору. У кожному творі наявні художній простір і час, однак вони не є абстрактними поняттями, а являють собою конкретні, тісно переплетені між собою складники твору. Дослідження думок, дій персонажів у часово-просторових координатах сприяє більш глибокому розумінню авторського задуму, а також художньої канви літературного твору.
Аналіз останніх досліджень і публікацій. Художній простір активно досліджувався й нині вивчається в літературознавстві. Учені, які досліджували часопросторову проблематику, робили акцент на суб'єктивнім характері відчуття часу, його залежності від інтенсивності переживання явищ і подій. Так, С. Скварчинська одна 3 перших ужила термін «закритий» і «відкритий» простір (Скварчинська, 1954), який згодом став предметом детального дослідження у Д. Лихачова (Лихачов, 1987) і Ю. Лотмана (Лотман, 2002). О. Чичерін увів 
у літературознавчий обіг таке поняття, як «пам’ять природи». За М. Бахтіним, часопросторові єдності $\epsilon$ «організаційними центрами основних подій твору, тому мають сюжетотворче значення» (Бахтін, 1975). Хронотоп конкретних літературних творів досліджує Н. Мафтин (Мафтин, 2018). Тим не менш художня природа хронотопу, його ознаки і способи подання в тексті, визначення функцій часопростору в літературному творі залишаються актуальними й до сьогодні, адже «аналіз літературного твору крізь призму дослідження художнього часопростору містить великий потенціал для виявлення домінант творчості, світоглядних позицій автора, зв'язку між ідейним змістом і формою» (Мафтин, 2018: 164).

Формулювання мети i завдань статті. Твір Люко Дашвар «Покров» іще не був предметом дослідження в аспекті зображення в ньому часопростору. Звертаючись у нашій роботі до типологічного аналізу специфіки моделювання часопросторових координат у зазначеному творі, маємо на меті дослідити суть поняття «хронотоп», вивчити деякі його загальні закономірності розвитку й подати спробу класифікації, розкрити взаємозв'язок хронотопу з жанровою природою зазначеного твору й використані прийоми відображення в ньому часового простору, розкрити майстерність українського прозаїка у царині композиції.

Виклад основного матеріалу дослідження. На наш погляд, у природі хронотопу закладено безліч можливостей. Суть цього терміна 3 часом змінюється, а деякі трактування вражають своєю оригінальністю та неординарністю. Термін «хронотоп» спричинює дискусії на шпальтах літературознавчих часописів. Простір і час можна віднести до важливих філософських категорій, без яких світоглядна модель реальності стає неможливою. На певних етапах розвитку час і простір уможливлюють створення складної системи, яка відображає часопросторові відношення різних типів.

Кожен літературний твір - це певний комплекс часопросторових компонентів. Теорія хронотопу дає велику кількість можливостей. Хоч трактування цього терміна 3 плином часу міняється, однак зазначимо, що наявні також деякі загальні закономірності розвою цього поняття. Трактування деякими літературознавцями цього поняття $\epsilon$ неординарними і вражають оригінальністю. Так, виокремлювалися й вивчалися деякі складники часу та простору, які були притаманні певній історичній епосі, відпрацьовувалися також відповідні жанрові літературні методи відтворення, що являли собою невід’ємну частину світу літератури.
Науковці вважають хронотоп найважливішим складником художнього світу твору, адже художній і реальний світи не існують поза часом і простором. Саме простір і час відбивають ідейноестетичні погляди й уподобання письменника. О. Ухтомський уперше використав термін «хронотоп» у науковому обігу. Ідею літературознавця розвинув і збагатив М. Бахтін, представивши хронотоп у вигляді системи просторово-часових значень. Дослідник стверджував, що хронотоп являє собою взаємозв'язок часопросторових відношень у літературі, який $\epsilon$ нероздільним. Хронотоп дозволяє об'єднати часові та просторові елементи у певну єдність; ці елементи не можуть функціонувати один без одного: «Час тут згущується, ущільнюється, стає художньо-зримим; простір же інтенсифікується, втягується в рух часу, сюжету, iсторії. Прикмети часу розкриваються в просторі, і простір осмислюється й вимірюється часом. Цим перетином рядів і злиттям прикмет характеризується художній хронотоп» (Бахтін, 1975).

На зламі XIX-XX ст. спостерігаємо виникнення нового бачення просторово-часових структур, яке дає розуміння наукового мислення XX ст. Нові філософсько-естетичні бачення навколишнього світу, місця в ньому людини, наукові умовиводи Ф. Ніцше, В. Соловйова, П. Успенського, А. Бергсона та багатьох інших культивують нові підходи до тлумачення й реалізації категорії часу та простору в мистецтві - літературі, кінематографі, музиці тощо.

Суттєвих змін картина світу зазнала не лише через вплив науки, філософської думки, нових естетичних поглядів, а й усього того, що відбулося впродовж перебігу історії людства. Завдяки модернізму виникла нова художня свідомість, підвалиною якої стало твердження про те, що людина може створити власний світ, який не залежатиме від об'єктивного світу, але є такий же реальний, значущий, як і дійсність. Саме це сповнило категорії часу та простору більш суб'єктивним, посилено особистісним за попередні епохи змістом.

Літературознавство зацікавилося дослідженням цих категорій у художній літературі досить недавно - із середини XX століття. Такі літературознавчі дослідження спершу містили здебільшого аналіз поглядів того чи іншого письменника щодо простору і часу, натомість не приділяючи уваги вивченню часу і простору художнього світу. Праця Д. Лихачова «Поетика давньоруської літератури», яка побачила світ у 1967 році, заклала підгрунтя глибокого вивчення структур часопростору в літературі. Аналізуючи категорії простору й часу, Д. Лихачов указав на особливості 
художнього осмислення цих категорій у різних літературних епохах: події, які розгортаються в літературному художньому тексті, можуть також збігатися 3 художнім часом самого автора. У художньому творі «час може випереджати певні події або відставати від них» (Лихачов, 1987).

Юрій Лотман досить грунтовно працював над дослідженням простору художнього твору. Так, дослідник розмежував фантастичний і побутовий і простори, відкритий і замкнений. Художній простір у літературі він уважав безперервністю, у якій перебувають герої, але це також і події, що зображені у творі. Художній простір, на думку, Ю. Лотмана, не завжди $є$ природним, адже він проєктує взаємозв'язки картини світу: тимчасові, етичні, соціальні тощо. Літературний простір, розпадаючись, припиняє існувати як єдиний простір і трансформується у безліч інших просторів, які можуть бути зовсім не пов'язані між собою, а це створює хаотичність структури простору. Вона $є$ вагомим поетичним засобом у творі, бо в параметрах простору закладений естетичний вміст конкретної епохи: «Кожному художньому простору відповідає особливий тип стосунків, який реалізується в свідомості героїв» (Лотман, 2002: 30).

Художній час і простір зазвичай перебувають у певному взаємозв'язку. Художній час може досить строкато втілюватися в художньому творі: або ущільнювати, зменшувати межі оповіді, або ж, навпаки, розтягувати їх. Коли у тексті твору переважає опис, то це зумовлює можливість для письменника втілити авторське бачення світу. А от опис дозволяє читачеві зануритися в художній простір твору, де час нібито зупиняється.

Б. Роднянська наголошує на ейдологічній функції часу та простору: «Художній час і художній простір - найважливіші характеристики художнього образу, що забезпечують цілісне сприйняття художньої дійсності й організовують композицію твору» (Цит. за ((Шерстюк 2018: 60)).

Отже, на нашу думку, час і простір у художньому тексті перебувають у тісному взаємовпливі, час від часу трансформуються або модифікуються.

3-поміж хронотопів літературознавець В. Щукін визначає низку явищ дійсності: «зустріч, візит, спектакль, богослужіння, свято, подорож, побачення, одруження, інтимне зближення, сон, відпочинок, хвороба, судовий процес, тюремне ув'язнення, полювання, битва, катастрофа, народження, життя, смерть (як закінчений акт, а не безстроковий стан після цього акту), похорони, хрестини й багато іншого. Місто, будинок, корабель і цілий ряд численних локусів теж можуть пере- творитися в хронотоп, але лише в тому випадку, коли в їхньому просторі відбувається та триває процес або подія. Тоді ці хронотопи зручніше буде назвати по-іншому: життєдіяльність міста, життя (функціонування) будинку, плавання на кораблі» (Щукін, 2004: 58). Автор тут цілком слушно, із нашого погляду, висновує, що «жанр прагне до свого завершення в певному хронотопі часу-місця звершення» (Щукін, 2004: 60).

Отже, проведений огляд теоретичних робіт науковців, а також дослідження категорій часу та простору в літературному процесі дає підстави висновувати, що хронотоп є одним із найбільш перспективних понять сучасного літературознавства зокрема й гуманітарної науки взагалі, що дістало поштовх до вивчення після виходу грунтовних теоретичних праць Михайла Бахтіна. Художній час і художній простір натепер залишаються дискусійними поняттями в літературознавстві, що лише розпалює до них інтерес дослідників. Їхня дискусійність зумовлена не лише різними підходами літературознавців до цих категорій, а й їхніми багатозначністю та умовністю, що корелюється природою самого мистецтва. Часопросторові образи в художній літературі тісно переплетені з філософськими роздумами самого наратора, бо ж вони є відбиттям його життєвої позиції й деяких житейських установок. Власне ставлення до певної події наратор висловлює здебільшого завдяки описовості. Важливою особливістю художніх образів часу та простору вважається те, що автор ніколи не буває абсолютно байдужим i відстороненим, а завдячуючи цьому всі образи, створені ним, мають виразні індивідуальні риси.

Не претендуючи на остаточність, вважаємо хронотоп сукупністю просторово-часових перетинів у тексті художнього твору, які системно взаємопов'язані. Вони об'єднують складники художнього тексту та окреслюють його межі. Хронотоп - це, перш за все, індивідуальний авторський світ, у якому зображено події, представлені в літературному творі. Художній час і простір вважаємо найважливішими засобами втілення й вираження авторської інтенції.

Репрезентація просторових і часових характеристик у творі $є$ показовою і значущою для виявлення авторської концепції світу у творі Люко Дашвар «Покров». Символічним $\epsilon$ початок досліджуваного твору, у якому оповідь замикається лексемою «час»: «Уже ц̌ час?» (Люко Дашвар, 2015). Отже, з перших рядків твору маємо вихід нервового волокна оповіді на поверхню. Подальший детальний опис приготувань до смерті (напружено, але сплановано Криващиїхою) має 
свою композиційну завершеність: це композиція жанрової картини, дії, застиглої на полотні.

Автор часто поєднує теперішній, минулий i майбутній часи в одній змістовій площині:

Змилуйтеся, бабо Кривошийхо! Урятуйте Ярему Петровича! Ще вчора верхи стрілою літали. А веселі ж були! А дужі! ... Не втерпіли, зайшли до курильні, а Ярема Петрович на долівиі хриплять...

Савко замовк на мить, на бабу зиркнув.

- Бабо, чуєте? Як хазяїн помруть, і мені не жити! (Люко Дашвар, 2015).

Люко Дашвар, здавалося б, фіксує тільки зовнішні вияви психічного стану свого героя в момент усвідомлення безповоротності втрати, однак ця «зовнішність» якнайглибше передає межовість його стану, про що свідчать спогадиретроспекція Яреми:

Чого йому перед смертю бажати? Сонще побачити. I як тій ворожиі пояснити, щзо сонце має ім'я, чорні брови, густі вї й такі сині очі, що душа плаче від щастя, варто лише їх згадати?» (Люко Дашвар, 2015).

Твору Люко Дашвар властиве чергування динаміки й статики. Автор зображує минулі історії Дороша як марення, як «сповідь» перед смертю в присутності Кривошиїхи.

Минуле, теперішнє і майбутнє часто співіснують в одному абзаці:

Хотинський вразив Аду Озерову в самісіньке серие. Побачила доччиного кохания, аж згадала: ось вона наївна, юна гортає каталог одягу «QUELLE», який за дві жувальні гумки випросила до вечора в однокласнииі Тоньки Захарченко... Радянська школярка Ада жбурляе каталог геть, валиться на постіль, ридає гірко, бо ж їи -хоч би якого з тих красенів! Хоч русявого, хоч чорнявого, та нема... Нема в Києві таких! Певно, в усьому Радянському Союзі нема! I як з тою бідою жити?!

Відігнала минуле, узяла себе в руки (Люко Дашвар, 2015).

Композиційним прийомом відображення часового простору в романі є звертання Яреми Петрова Дороша до сьомого коліна що й об'єднує всі зображені перипетії твору.

Кривошиїха насупилася, забубоніла:

- ... Не баріться, пане Дороме... Спливає ваш час. Кличте предків ваших до сьомого коліна, як хочете красної долі для дітей-онуків ваших.

- Мамо... - прохрипів Дорош слабко. - Нене моя рідненька. Ганно Миколаєва, в дівоцтві Кандиба. Поможіть сину вашому, Христом-Богом прошу. Батьку... Петре Андріїв Дорош. Не гні- вайтеся. Станьте до захисту. Діди мої славні... Андрію Никифорів Дорош, Миколо Семенів Кандиба... Баби мої милостиві... Параско Іванова, у дівоцтвв Перелаз, Мотре Федоріва, у дівоцтві Соловатова... Не полиште сім'я правнука свого на погибель (Люко Дашвар, 2015).

Ще одним прийомом такого зображення $\epsilon$ ретроспекція, наприклад, думки Перпетуї про майбутнє: Не за себе душа болить. За прийдешніх, ще ненароджених... (Люко Дашвар, 2015). Або уривок, де йдеться про плани Перпетуї на сто тридцять років наперед:

- Я не забиратиму золото, - відповіла жінка. Хочу розмістити його у вас під добрий відсоток на сто тридиять років.

- На скільки?! - здивувався банкір, одразу взявся рахувати подумки. - Тобто... до дві тисячі одинадиятого року?! (Люко Дашвар, 2015).

Іноді автор вдіється до кадровості:

Тридиять сім років потому в одному з банків Монреаля:

За тридиять сім років, навесні 1881-го, до канадського «Банку Монреаля» завітала скромно вбрана сива пані... (Люко Дашвар, 2015).

Крізь увесь твір проходить образ Дороша. Так, їдучи до чужої країни на пароплаві, Перпетуя бачить примару в образі Яреми. Він схвалює іiі вчинки:

Далеченько стояв, $і$ хоч судно похитувалося мляво, Ярема - мов та скеля: ані руху, ані сумніву. Дивився Перпетуї в очі схвильовано, тільки вітер сиве волосся куйовдив. Задихнулася, руки до грудей приклала... Ярема кивнув схвально, ніби підтримував геть усе, шо Перпетуя за життя вдіяла, $і$ щуез (Люко Дашвар, 2015).

Другий розділ книги переносить читача в наш час - у 2013 рік. Така раптова розімкнутість застиглого часу й обмеженого простору дає неясну надію й також свідчить про кадровість як засіб відображення часового простору. Однак подальший виклад - знову напружений і динамічний, адже йдеться про революційні події.

Історія Дороша триває і в наш час. Його ім'я пов'язує давні й сьогоднішні події. Шукаємо разом з героями сто двадцять шосте ім'я.

Прийомом відображення часового простору $\epsilon$ згадки героїв про цінність родоводу, коріння для людини:

- Ми з Мар'яною понад усе иінуємо наші корені, - повідомив довірливо. - От вам пощастило! Маєте змогу щзодня торкатися історії нашого народу (Люко Дашвар, 2015).

У творі здебільшого емпірична, видима реальність, що є відображенням інформаційного світу 
структур, протікає в часі, у позаемпіричній панує вічність. Тому саме у спогадах, як виході на інформаційний світ структур, можна повернутись у минуле, у якому був щасливий, наче в сьогодення: у спогадах героїв панує не динамічна концепція часу, а статична:

Ox, ті суконьки, бабиними руками шиті. Усе економила, бідаха. Іншим дівчаткам батьки в магазинах стандартну шкільну форму купували, а метикувата баба Тася - обрізки та залишки тканини, щзо їх віддавали за безцінь. Ніч над клаптями поворожить, на ранок - ану, примірь, серденько! Може, десь вщити чи відпустити треба. Через ті сукні дівчатка в класі заздрощами сходили, бо всі-однакові, а в Ади суконька особлива: i спідничка кльошем, $і$ комірчик гострий, і рукавчики ліхтариками... (Люко Дашвар, 2015).

Отже, філігранно вибудована завдяки майстерній грі з часом композиція досліджуваного твору, однак, не становить самоцілі для Люко Дашвар. Зіставляючи різні часопросторові виміри, автор намагалася виявити як характеристичні властивості «тут» і «тепер», так і загальні, універсальні закони буття, осмислити світ в його єдності, показати абсурдність ворожнечі.

Висновки та перспективи досліджень у цьому напрямі. Отже, на нашу думку, хронотоп являє собою одне 3 найбільш затребуваних і перспективних понять гуманітарної науки, адже художній час i художній простір і нині залишаються дискусійними поняттями в літературознавстві. Їхню неоднозначність, дискусійність можна пояснити не лише різними підходами науковців до вивчення цих катего- рій, а й їхніми умовністю й певною невизначеністю, а це випливає з природи самого мистецтва. У досліджуваному творі часопросторові художні образи тісно переплетені $з$ філософськими поглядами й роздумами самого наратора.

Важливою особливістю художніх образів часу та простору досліджуваного твору $є$ те, що тут автор ніколи не буває повністю відстороненим чи байдужим, і тому всі образи, створені ним, мають виразні індивідуальні риси. Звідси випливає, що хронотоп - це передовсім авторсько-індивідуальний світ, у якому відображено події літературного твору.

Художній час і простір твору є важливими способами втілення авторської інтенції. Репрезентація просторових і часових параметрів у творі $\epsilon$ глибокою й тому значущою для виявлення концепції світу митця.

Автор досліджуваного роману майстерно використав просторово-часову композицію як особливий, усвідомлений художній прийом. Ведучи «гру» 3 часом і простором, задіяв можливості для цікавих композиційних багатоходівок, завдяки чому досягнуто справді досконалої архітектоніки. У творі наявне обрамлення, ретроспекція, розрив подій у часі, які реалізуються в численних спогадах героїв, листах, снах, «оживленні» подій, засвідчених в архівах тощо.

У творі використано і прийоми зображення соціально-історичного часу, характерна подвійна розв'язка, що посилює емоційний ефект. Завдяки застосуванню прийому концентричних переходів буття в марення сюжет розгортається в насичені подієвістю структури.

\section{СПИСОК ВИКОРИСТАНИХ ДЖЕРЕЛ}

1. Бахтин М. М. Формы времени и хронотопа в романе. Очерки по исторической поэтике. Москва : Худож. лит., 1975. C. 234-407.

2. Копистянська Н. Хронотоп як аспект вивчення слов'янського романтизму (на матеріалі західнослов'янських літератур у європейському контексті). Слов'янські літератури : Доповіді. ХІІ Міжнародний з'їзд славістів (Краків, 27 серпня - 2 вересня 1998). Київ, 1998. С. 57-74.

3. Лихачев Д. С. Поэтика древнерусской литературы. Москва : Наука, 1987. 624 с.

4. Лотман Ю. М. Статьи по семиотике культуры и искусства. СанктПетербург : Акад. проект, 2002. 544 с.

5. Мафтин Н. В. Типологія моделювання хронотопу в новелах Юрія Яновського «Поворот» та Амброуза Бірса «Випадок на мосту через Совиний рівчак». Прикарпатський вісник НТШ. Слово. № 3(47). 2018. С. 163-173.

6. Шерстюк Н. Хронотоп як літературознавча категорія: генеза, еволюція, дискурс. Філологічні науки. 2018. № 28. С. 56-61.

7. Щукин В. Г. О филологическом образе мира (философские заметки). Вопросы философии. 2004. № 10. С. 47-64.

8. Skwarczyńska S. Wstęp do nauki o literaturze. T. 1. - Warszawa. Pax, 1954. - S. 124-138.

\section{ДЖЕРЕЛА ІЛЮСТРАТИВНОГО МАТЕРІАЛУ}

1. Люко Дашвар. ПоКров. Харків : Книжковий клуб «Клуб сімейного дозвілля», 2015. 384 с. URL : https://www.litmir.me/br/?b=276160 (дата звернення: 11.11.2021).

\section{REFERENCES}

1. Bakhtin M. M. (1975) Formy vremeni i khronotopa v romane. Ocherki po istoricheskoy poetike. [Forms of time and chronotope in the novel. Essays on historical poetics]. Moskva : Khudozh. lit. [in Russian]

2. Kopystianska N. (1998) Khronotopyak aspekt vyvchennia slovianskoho romantyzmu (na materializakhidnoslovianskykh literatur u yevropeiskomu konteksti) [Chronotop as an aspect of the study of Slavic romanticism (on the material of Western 
Slavic literature in the European context)]. Slovianski literatury. Dopovidi. KhII Mizhnarodnyi zizd slavistiv. Kyiv, 57-74 [in Ukrainian].

3. Likhachev D. S. (1987) Poetika drevnerusskoy literatury [Poetics of ancient Russian literature]. Moskva : Nauka [in Russian].

4. Lotman Yu. M. (2002) Stati po semiotike kultury i iskusstva [Articles on the semiotics of culture and art]. Sankt-Peterburg : Akad. proekt [in Russian].

5. Maftyn N. V. (2018) Typolohiia modeliuvannia khronotopu v novelakh Yuriia Yanovskoho «Povorot» ta Ambrouza Birsa «Vypadok na mostu cherez Sovynyi rivchak» [Typology of chronotope modeling in Yuri Yanovsky's short stories "Turn" and Ambrose Beers "The case on the bridge over the Owl Creek"]. Prykarpatskyi visnyk NTSh. Slovo. № 3(47), 163-173 [in Ukrainian].

6. Sherstiuk N. (2018) Khronotop yak literaturoznavcha katehoriia: heneza, evoliutsiia, dyskurs [Chronotope as a literary category: genesis, evolution, discourse]. Filolohichni nauky. № 28. S. 56-61 [in Ukrainian].

7. Shchukin V. G. (2004) O filologicheskom obraze mira (filosofskie zametki) [About the physiological image of the world (philosophical notes)]. Voprosy filosofii. № 10, 47-64 [in Russian].

8. Skwarczyńska S. (1954) Wstęp do nauki o literaturze [Introduction to the study of literature]. T. 1. - Warszawa. Pax, 124-138 [in Polish].

\section{SOURCES OF ILLUSTRATIVE MATERIAL}

1. Liuko Dashvar (2015) PoKrov [The cover] [in Ukrainian]. 